Svetlana A. Mozgot

Doctor of Arts, Associate Professor,

Professor, Institute of Music, Theater

and Choreography at the A.I. Herzen

State Pedagogical University of Russia prostranstvo30@yandex.ru

Russia, St. Petersburg

ORCID 0000-0002-5342-6940

DOI: $10.36340 / 2071-6818-2020-16-1-144-156$

\title{
Phenomenon of Spatial Representations in Music: Psychophysiological Aspects
}

Summary: The article is devoted to exploration of the functions of visual thinking in the formation of spatial representations in human knowledge, which help to recognize the meanings of musical compositions. The purpose of this work is to study "visual" ways of spatial perception of musical works, in which eye-mindedness of the composer is implemented in specific operation by expressive means of music. Methods of hermeneutics, comparativistics, musicological analysis and interdisciplinary approach are used to realize this purpose. Principles of visual perception - simplicity and influence of geometric form on emotional properties of the object in music - are regarded as an example to show how they act. Principle of simplicity is evident in the organization of the form of "second plan" which unites multiple-part structures in music, tonal development, according to the type of "the highest order functions". Influence of geometric form on emotional properties of the object in music is defined by the correlation of statics and dynamics in the development of a musical work; in semantics of geometrical figures "visualizing" in the graphic of melodic line or form of texture, which is supported by musical examples.

We draw the conclusions that the existence of these principles in music helps to structure and store information about music in simple mental models, which are easy to recall. Interaction of means of musical expression gradually forms an in the consciousness of the listener, which contains certain spatial and visual characteristics, helping to recognize its real prototype, its artistic sense and meanings. Finally, the ontology of the category of space itself causes availability of a number of universal laws that ensure the convergence of different types of art in the act of artistic creativity and perception. It can be stated that the process of musical perception is dependent on the proceeding and results of different kinds of thinking, which are based on the already available knowledge about the reality and specifics of its reflection. Important components in perception are the nature of the organization of thought processes - attention, imagination, memory; the pace at which thought operations are performed - analysis, synthesis, comparison, 
generalization, concretization and abstraction, and a variety of other internal human properties and qualities. Understanding these patterns is possible not only based on the study of human psychophysiology, but also, on the contrary, through the study of the principles of the impact of art on man in an interdisciplinary aspect.

Keywords: perception, art space, the principle of simplicity, psychophysiology, an interdisciplinary approach.

Most often, according to psychologists1, the peculiarities of space perception rely on sensory experience (visual, audio, kinesthetic, orientative reflex and other channels of sensory perception), which "supplies" our consciousness with "metric" parameters both of the body itself and the physical space surrounding it. Throughout the history of music, the composers deliberately influenced the perception of man with the power of various mechanisms of activation of different kinds of thinking in attempt to create an adequate reflection of the spatial image of the world.

This work focuses on the study of "visual" ways of spatial perception of musical compositions, in which eye-mindedness of the composer is implemented in specific operation by expressive means of music.

Methods of hermeneutics, comparativistics, musicological analysis and an interdisciplinary approach are used to implement this goal.

We believe that visual image-bearing thinking has the special significance in spatial perception in music. This assumption is based on the research by M. Sh. Bonfeld, who has argued that "the musical thinking is non-verbal thinking basing on musical non-verbalized entities (concepts, representations, etc.) in which the solution of figurative, constructive and other tasks takes place. These entities are quite naturally transformed into linguistic quasi-space representations, in which often various spiritual, moral concepts and symbols are expressed in metaphoric form, in special hierarchical constructs" 2 . In such a context, the influence of a multitude of cultural objects surrounding a person becomes essential to his perception. We can suggest that the external art space has an effect on creation of an extensive network of associative and intertextual connections in the inner world of man. Their functionality is linked to the integration and complementarity of the content of works of different kinds of art in mental activity of a perceived person, "creating a rich field of meanings, equivalent to obtaining the maximum of aesthetic pleasure" 3 .

In this study, the artistic space is understood in a broad and narrow sense. In broad sense, it can be conceived as a space formed by artistic activities. Accordingly, institutions related to artistic activities - museums, libraries, theatres, cultural and artistic education institutions should have their own artistic space and form the artistic space of the subject.

In a narrow sense, projecting L. P. Kazantseva's definition of artistic meanings on the concept of artistic space, it is possible to imagine it in the form of integrity, formed by means of two or more kinds of art4. Such an understanding of artistic space provides an opportunity to step up to the detailed study of artistic space in synthetic types of art - 
cinema, theatre, opera, musical and dramatic productions. In order to understand the specifics of artistic space as a holistic and independent phenomenon, we shall narrow down ideas about it as a space created according to the laws of visual kinds of art, basing on the laws of visual perception. It is this fact that the phenomenon of artistic space exists in practice, substantiates the fact that even the real, physical space of the subject, organized by the designer according to the laws of visual arts, begins to have the properties of art. It interacts with the perceived viewer as a holistic artistic object, possessing its own internal meanings, affecting the perceived man. Then the question arises as to what principles underlie this effect.

According to L.E. Etingen, about $90 \%$ of the information is perceived by vision5. We can assume that the laws of visual perception, basing on spatial dimensions, become the basis for launching processes of knowledge and recognition, both of objective phenomena of reality and other subjective meanings in different types of art, including music. This observation is supported, in our opinion, by the presentation of musical production in concert halls, where the space is conditionally divided into stage and visual. Such arrangement unconsciously brings into action the mechanisms of perception of audio phenomena as visual, i.e., as if placed on a plane (like a film screen), activating the operation of the corresponding sensory systems. That is, the laws of visual perception work unconsciously, organizing all incoming information outside the definition of which sensory channel is dominant - visual or audio.

Principle of simplicity. One of the important laws of visual perception is that, according to R. Arnheim, "the perception does not begin with particulars. On the contrary, its starting point is universality" 6 . A person easily and instantly perceives any elementary forms, for example, a circle or a square, as well as forms, which approach element-shaped. This is the basis for the principle of simplicity in art. At the same time, "simplicity cannot be determined only by the number of elements of the composition. Sometimes a composition with more elements can still have a simpler structure" 7 . The effect of the principle of simplicity is observed in the organization of musical forms, when multiple-part compositions are structured into larger, simple structures. For example, Rhapsody on a theme of Paganini by S. V. Rachmaninov, written in variation form, and 32 variations of L. Beethoven are divided into groups and set into a threepart cycle. The famous aria of Ruslan from the second action of the opera "Ruslan and Ludmila" by M.I. Glinka, written in the allegro-sonata form with introduction, can be considered as a two-part form. The effect of the principle of simplicity in art creates conditions for learning and storing information in a person 's mind in simple models that are easy to recover in memory.

The principle of simplicity is also applied in the construction of tone plans, where the transition from one tonality to another is perceived through the logic of normal functional relations in single-tone work, but the whole tone development of the composition is generalized as the highest order functions. Functions of the highest order act as a distribution of dynamics and statics in tonality, which B. L. Yavorsky was deeply engaged 
in. I. Ya. Ryzhkin continued his study, justifying that the correlation of dynamics and statics has expressive-emotional properties and, manifesting in a special way, including through the form of a musical work, impacts on musical perception8.

Principle: Shape geometry defines the emotional properties of an object

From the most ancient times, a distinct semantics has been attached to every geometric structure in the fine form of art. For example, a square is associated with statics, stability, rest, reliability, monumentality, and significance9. The unconscious sense of inviolability and stability of the shape of the square was formally approved in the music of the era of classicism in the structure of the symmetrical period of repeated structure, as a reflection of the belief of the society in harmony, sense and inviolability of nature and the universe.

The emotional expressiveness of the square was perceived by composers in different ways. V. Zuckerman expressed these sensations in figurative form in such a way. "D. Scarlatti perceived the square as "the clothes, hampering movements, ... worn without desire" and interfering with the expression of the flow of life-joyous energy. For French clavecinists, it was congenial because it was not in contradiction with their inherent ceremonious rhythmicity. For classics, the square was felt as "fancy outfit full of simplicity and dignity" 10 .

Breaking and changing the shape of the square period often reflected game logic and was viewed as an expression of dynamics. The shape of the square naturally flowed into the shape of a rectangle when there were used scale-themed expansion structures, for example in Mozart's sonatas ( $F$-dur, part 1; D-dur, part 2), comic-scherzo additions at Haydn (in part 1 of the quartet Es-dur op.71 No. 3), and additional-complementary thought of cadences in Beethoven sonatas (sonata 18 Es-dur, part 1).

The shape of the rectangle also did not contradict the aesthetics of classicism, because archetypally expressed "the dynamics, steady orientation, and calm spatial extension" 11 in the pictorial art. It is worthy of noting that the emotional-expressive properties of geometric forms in music are not always directly related to structure alone. For example, the illusion of a rectangular structure can also arise when the structure is square, but when using a texture organized in analogy to a chorale. Such is the transition in part 1 of Sonata No. $5 \mathrm{c}$-moll, and the second theme in part 1 of Sonata No. 21 by L. Beethoven. The contrast of the horizontal of the development of the one theme as opposed to the vertical of the other makes it possible to perceive the difference in the geometric bases of the musical form most distinctly. For example: 
Primary area, part 1 of sonata 5

of L. Beethoven

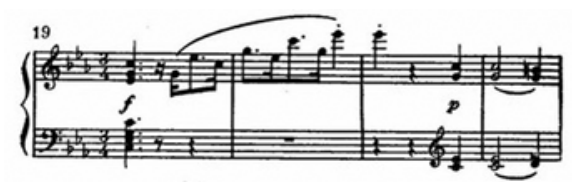

Primary area, part 1, sonata 21 of

L. Beethoven

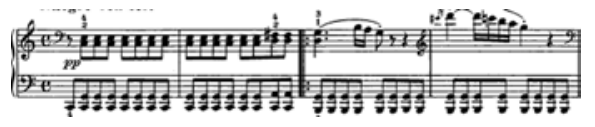

The transition, part 1 of sonata 5

of L. Beethoven (bars 7-22)

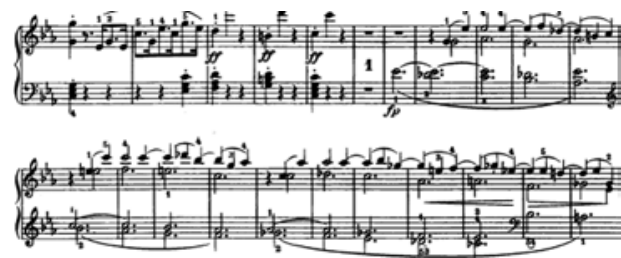

Secondary area, part 1, sonata 21 of

L. Beethoven (bars 4-10)

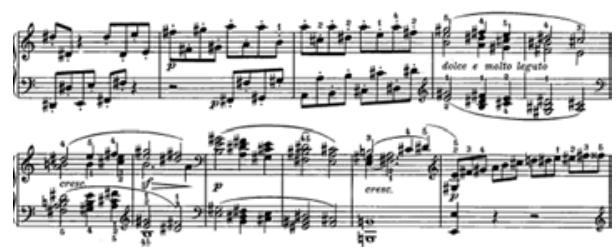

The rectangular boxes elongated upwards are perceived as expression not only of slenderness and elegance, but also as the desire for "high" 12 .

In the age of Romanticism, the departure from the symmetry of square period was an expression of the dynamics of feeling formation, the dynamics of eventuality. Therefore, it is logically natural that the structure of the theme began to resemble triangles with various forms of apex displacement to the right or left. Thus, we find a triangle with a shifted apex to the right in the first parts of sonatas 5, 8, 23 by L. Beethoven, in the Minuet of Symphony No. 40 by V. Mozart. Such a theme structure serves as an expression of "directed vigorous dynamics" 13 , showing the aggressiveness, the "unaccommodating nature" of one of the elements of the theme. At the same time, the beginning of the theme from the top of the source, shifting the triangle-apex to the left, causes a calmer, pacified state due to the decline of the wave, such as in Chopin 's nocturne Des-dur. In music, one can find an embodiment of isosceles, symmetrical triangles as well, as in the theme of joy in Part 4 of L. Beethoven 's Ninth Symphony and in the musical number of "Juliet as a Young Girl" from S. Prokofiev's ballet "Romeo and Juliet".

Thus, having considered the effect of two important principles (simplicity and the influence of shape geometry on the emotional properties of the object), acting in the spatial visual perception of man, we understand that the ontology of the category of space itself causes the existence of a number of universal laws ensuring the convergence of different types of art in the act of artistic process and perception. It is natural that the interaction of means of musical expression promotes to a gradual creation of an image in 
the consciousness of the listener, having certain spatial and visual characteristics, helping to recognize its real prototype, its artistic senses and meanings.

As a result, it can be stated that the process of musical perception is dependent on the proceeding and results of different kinds of thinking, basing on the already available knowledge about the reality and specifics of its reflection. An important component in perception is the nature of the organization of thought processes - attention, imagination, memory; as well as the pace of thought operations, such as analysis, synthesis, comparison, development, concretization and abstraction, and a variety of other individual human properties and qualities. Understanding these patterns is possible not only on the basis of the study of human psychophysiology, but also, on the contrary, through the study of the principles of the impact of art on man in the cross-discipline aspect.

\section{REFERENCES}

1. Arnkheym, R. 1974. Iskusstvo i vizual'noe vospriyatie [Art and Visual Perception], Moscow, p. 12.

2. Bonfeld, M. Sh. 2006. Muzy'ka: Yazy'k. Rech'. My'shlenie. Opy't sistemnogo issledovaniya muzy'kal'nogo iskusstva [Music: Language. Speech. Thinking. Experience in systemic research of musical art]. SPb, p.648

3. Vekker, L.M. 2000. Psixika i real'nost': edinaya teoriya psixicheskix processov [Psyche and Reality: A Single Theory of Mental Processes], Moscow, p.587

4. Kazantseva, L.P. 2005. Soderzhanie muzy'kal'nogo proizvedeniya v kontekste xudozhestvennoj kul 'tury' [Content of musical work in the context of artistic culture], Astrakhan, p.112

5. Kryuchkova, K.K. 2014. Kompoziciya v dizajne [Composition in design], Maykop, p.426

6. Raykov, V.L. 2005. Znachenie ponimaniya soznaniya [Significance of understanding consciousness], Moscow, p.164

7. Ryzhkin, I. Ya. 1939. "Teoriya ladovogo ritma" ["Tonality rhythm theory"], Essays on the history of theoretical musicology, issue 2, p.286

8. Sveshnikov, A.V. 2017. Integral'noe my'shlenie i iskusstvo [Integral thinking and art], Moscow, p. 324

9. Zuckerman, V.A. 1975. Analiz muzy'kal'ny'x proizvedenij [Analysis of Musical Works, Moscow, p. 677.

10. Etingen, L.E. 2009. Mifologicheskaya anatomiya [Mythological Anatomy], Moscow p.344

11. Tang, Kuo Hao \& Chen, Shih \& Tsai, Yu-Ting. 2016. "Assessment of the subjective perception of music quality using psychoacoustic approach", International Journal of Industrial Ergonomics, no. 53, pp. 219-228. DOI: 10.1016/j.ergon.2016.01.004. 


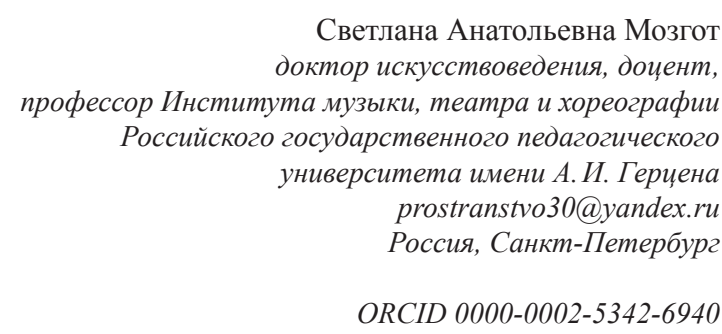

DOI: $10.36340 / 2071-6818-2020-16-1-144-156$

\section{Феномен пространственных репрезентаций в музыке: психофизиологические аспекты}

Аннотащия: Статья посвящена выявлению функций наглядно-образного мышления в формировании пространственных репрезентаций в сознании человека, помогающих распознаванию смыслов музыкальных произведений. Цель работы исследование «визуальных» способов пространственного восприятия музыкальных сочинений, в которых наглядно-образное мышление композитора реализуется в специфическом оперировании выразительными средствами музыки. Для реализации цели используются методы герменевтики, компаративистики, музыковедческого анализа, междисциплинарный подход. На примере существования принципов визуального восприятия - простоты и влияния геометрической формы на эмоциональные свойства объекта в музыке - показывается их действие. Принцип простоты проявляется в организации формы «второго плана», объединяющей многочастные структуры в музыке, в организации тонального развития, по типу «функций высшего порядка». Влияние геометрической формы на эмоциональные свойства объекта в музыке передаётся соотношением статики и динамики в развитии музыкального произведения; в семантике геометрических фигур, «визуализирующихся» в графике мелодической линии или складе фактуры.

Делаются закономерные выводы о том, что существование этих принципов в музыке помогает структурировать и хранить информацию о музыке в простых ментальных моделях, которые легко восстановить в памяти. Взаимодействие средств музыкальной выразительности постепенно в сознании слушателя формирует образ, обладающий определёнными пространственными и визуальными характеристиками, помогающими распознать его реальный прототип, его художественные смыслы и значения. В итоге сама онтология категории пространства обусловливает существование ряда универсальных законов, обеспечивающих сближение разных видов искусства в акте художественного творчества и восприятия. Можно констатировать, что процесс музыкального восприятия напрямую зависит от протекания и результатов разных видов мышления, опирающихся на уже имеющиеся знания 
о реальности и специфике её отражения. Важными составляющими в восприятии являются характер организованности мыслительных процессов (внимания, воображения, памяти); темп осуществления мыслительных операций (анализа, синтеза, сравнения, обобщения, конкретизации и абстракции) и множество других внутренних индивидуальных свойств и качеств человека. Понимание этих закономерностей возможно не только исходя из исследования психофизиологии человека, но и, наоборот, через изучение принципов воздействия искусства на человека в междисциплинарном аспекте.

Ключевые слова: восприятие, художественное пространство, принции простоты, психофизиология, междисииплинарный подход.

Наиболее часто, по мнению психологов ${ }^{1}$, особенности восприятия пространства опираются на сенсорный опыт (визуальные, аудиальные, кинестетические, ориентировочные и другие ощущения), «снабжающий» наше сознание «метрическими» характеристиками как самого тела, так и окружающего его физического пространства. Композиторы на протяжении истории музыки сознательно воздействовали на восприятие человека при помощи разнообразных механизмов активизации разных видов мышления в попытках создать адекватное отражение пространственного образа мира в своих творениях.

Цель работы - исследование «визуальных» способов пространственного восприятия музыкальных сочинений, в которых наглядно-образное мышление композитора реализуется в специфическом оперировании выразительными средствами музыки.

Методы исследования - герменевтики, компаративистики, музыковедческого анализа, междисциплинарный подход.

Наше предположение об особой значимости наглядно-образного мышления в пространственной перцепции в музыке основывается на идее М. Ш. Бонфельда, утверждавшего, что «музыкальное мышление есть мышление невербальное с опорой на музыкальные невербализуемые сущности (понятия, представления, др.), при котором происходит решение образных, конструктивных и иных задач. Эти сущности вполне естественно трансформируются в языковые квазипространственные представления, в которых нередко в метафорической форме, в особых иерархических конструктах находят выражение различные духовные, нравственные понятия и символы» ${ }^{2}$. В таком контексте влияние множества культурных объектов, окружающих человека, становится существенной составляющей его восприятия. Можно предположить, что формируемое внешней средой художественное пространство

1. Веккер Л.М. Психика и реальность: единая теория психических процессов / общ. ред. А. В. Либина.- М.: Смысл, 2000.-587 с.; Райков В. Л. Значение понимания сознания.М.: Синергия, 2005. - 164 с. 349.; Kuo Hao Tang. Assessment of the subjective perception of music quality using psychoacoustic approach // International Journal of Industrial Ergonomics. 2016. - Vol. 53.- Pp. 219-228.

2. Бонфельд М. Ш. Музыка: Язык. Речь. Мышление. Опыт системного исследования музыкального искусства.- СПб.: Композитор, 2006.- С. 37. 
воздействует на создание во внутреннем мире человека разветвлённой сети ассоциативных и интертекстуальных связей. Их функциональность связана с объединением и взаимодополнением в мыслительной деятельности воспринимающего человека содержания произведений разных видов искусства, «создавая богатое поле смыслов, равнозначное получению максимума эстетического удовольствия» ${ }^{3}$.

В настоящем исследовании художественное пространство понимается в широком и узком смысле. В широком его можно представить как пространство, формируемое художественными видами деятельности. Соответственно, учреждения, связанные с художественными видами деятельностями - музеи, библиотеки, театры, учреждения культуры и художественного образования,- - должны обладать собственным художественным пространством и формировать художественное пространство субъекта.

В узком смысле, проецируя на понятие художественного пространства определение художественного содержания Л.П. Казанцевой, можно представить его в виде целостности, формируемой приёмами и средствами двух или более видов искусства ${ }^{4}$. Такое понимание художественного пространства даёт возможность подойти к детальному изучению художественного пространства в синтетических видах искусства - кино, театре, опере, музыкально-драматических постановках. Для понимания специфики художественного пространства как целостного и самостоятельного феномена позволим себе сузить представления о нём как о пространстве, созданном по законам визуальных видов искусства, опирающегося на законы визуального восприятия. Именно этот факт существования феномена художественного пространства в практике обусловливает то, что даже реальное, физическое пространство субъекта, организованное дизайнером по законам визуальных искусств, начинает обладать свойствами художественности, взаимодействуя с воспринимающим зрителем как целостный художественный объект, обладающий собственными внутренними смыслами, воздействующими на воспринимающего. Закономерно возникает вопрос о том, какие принципы обусловливают это воздействие.

По данным Л.Е. Этингена, при помощи зрения воспринимается около $90 \%$ информации ${ }^{5}$. Можно предположить, что законы визуального восприятия, опирающиеся на пространственные закономерности, становятся основой для запуска процессов распознавания и узнавания как объективных явлений действительности, так и других субъективных смыслов в разных видах искусства, и в том числе в музыке. Подтверждением этого наблюдения, на наш взгляд, является сама презентация музыкального произведения в концертных залах, где пространство

3. Свешников А. В. Интегральное мышление и искусство.- М.: Университетская книга, 2017.$324 \mathrm{c}$.

4. Казанцева Л. П. Содержание музыкального произведения в контексте художественной культуры.- Астрахань: Волга, 2005.-С. 15.

5. Этинген Л.Е. Мифологическая анатомия.- М.: Институт общегуманитарных исследований, 2009.- С. 22. 
условно разделено на сценическое и зрительное. Такое расположение бессознательно включает механизмы восприятия аудиальных явлений как визуальных, то есть как бы размещённых на плоскости (наподобие экрана кино), активизируя работу соответствующих сенсорных систем. То есть законы визуального восприятия работают бессознательно, организуя всю поступающую информацию вне различия, какой сенсорный канал является доминирующим: визуальный или аудиальный.

Принцип простоты. Одним из важных законов визуального восприятия является то, что, по мысли Р. Арнхейма, «восприятие не начинается с частностей; наоборот, его исходной точкой является всеобщность» ${ }^{6}$. Человек легко и мгновенно воспринимает любые элементарные формы, например круг или квадрат, а также формы, которые при восприятии приближаются к элементарным. Это служит основанием для действия принципа простоты в искусстве. При этом «простота не может определяться лишь числом элементов композиции. Иногда композиция с большим количеством элементов может иметь всё же более простую структуру» ${ }^{7}$. Действие принципа простоты мы наблюдаем в организации музыкальных форм, когда многочастные композиции структурируются на более крупные, простые структуры. Например: рапсодия на тему Паганини С. В. Рахманинова, написанная в вариационной форме, и 32 вариации Л. Бетховена в крупном плане разделяются на группы и укладываются в трёхчастный цикл. Знаменитая ария Руслана из второго действия оперы «Руслан и Людмила» М. И. Глинки, написанная в форме сонатного аллегро со вступлением, может быть рассмотрена как двухчастная форма. Действие принципа простоты в искусстве создаёт условия для усвоения и хранения информации в сознании человека в простых моделях, которые легко восстановить в памяти.

Принцип простоты действует и в построении тональных планов, где переход из одной тональности в другую воспринимается через логику обычных функциональных отношений в однотональном произведении, но всё тональное развитие произведения обобщается как функции высшего порядка. Функции высшего порядка действуют как распределение динамики и статики в ладу, чем глубоко занимался Б. Л. Яворский, продолжил И. Я. Рыжкин, обосновывая то, что соотношение динамики и статики имеет выразительно-эмоциональные свойства и, по-особому проявляясь в том числе и через форму музыкального произведения, воздействует на музыкальное восприятие ${ }^{8}$.

Принизип: геометрия формы определяет эмоциональные свойства объекта

В изобразительном виде искусства за каждой геометрической конструкцией с самых древних времён закрепилась собственная семантика. Например, квадрат связывается со статикой, устойчивостью, покоем, надёжностью, монументальностью

6. Арнхейм, Р. Искусство и визуальное восприятие.- М.: Прогресс, 1974.- С. 12.

7. Там же. С. 14.

8. Рыљжкин И. Я. Теория ладового ритма // Очерки по истории теоретического музыкознания.М.; Л., 1939.- Вып. 2.— С. 107-108. 
и значимостью 9 . Бессознательное ощущение нерушимости и стабильности формы квадрата было формально утверждено в музыке эпохи классицизма в структуре симметричного периода повторного строения как отражение веры социума в гармоничность, разумность и незыблемость природы и мироздания.

Эмоциональная выразительность квадратности воспринималась разными композиторами по-разному. В. Цукерман в образной форме так выразил эти ощущения. Д. Скарлатти квадрат воспринимался как «стеснительная одежда, ...надеваемая без охоты» и мешающая выражению потока жизнерадостной энергии; для французских клавесинистов она была свойственна, поскольку не противоречила присущей им чинной размеренности; для классиков квадратность ощущалась как «красивое в своей простоте и достоинстве одеяние» ${ }^{10}$.

Нарушение и изменение формы периода квадратного строения зачастую было отражением игровой логики и рассматривалось как выражение динамики. При использовании масштабно-тематических структур расширения, например в сонатах Моцарта ( $F$-dur, 1-я часть; $D$-dur, 2-я часть), комически-скерцозных дополнений у Гайдна (в 1-й части квартета $E s-d u r$ op.71 № 3), досказывающе-дополняющих мысль каденций в сонатах Бетховена (18-я соната Es-dur, 1-я часть), форма квадрата естественно перетекала в форму прямоугольника.

Форма прямоугольника также не противоречила эстетике классицизма, поскольку архетипически в изобразительном искусстве выражала «динамику, устойчивую направленность, спокойную протяжённость» ${ }^{11}$. Примечательно, что эмоционально-выразительные свойства геометрических форм в музыке не всегда напрямую связаны только со структурой. Например, иллюзия прямоугольной конструкции может возникнуть и при квадратности строения, но при использовании фактуры, организованной по аналогии с хоралом. Такова связующая партия в 1-й части Сонаты № 5 c-moll, побочная партия в 1-й части Сонаты № 21 Л. Бетховена. Наиболее ярко различие геометрических оснований музыкальной формы воспринимается при контрасте горизонтали развития одной темы в противовес вертикали другой. Например:

9. Крючкова К. К. Композиция в дизайне.- Майкоп: Магарин О.Г., 2014.-С. 18.

10. Цукерман, В.А. Анализ музыкальных произведений. М.: Музыка, 1975.- С. 567.

11. Крючкова К. К. Композиция в дизайне.- Майкоп: Магарин О. Г., 2014.— С. 18. 
Главная партия, 1-я часть 5-й сонатыл Л. Бетховена

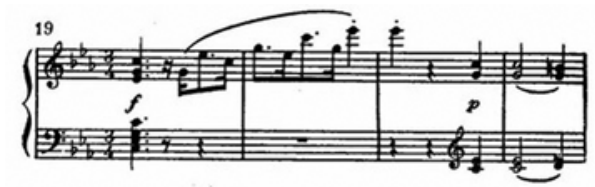

Связующая партия, 1-я часть 5-й сонатыл Л. Бетховена (тт. 7-22)

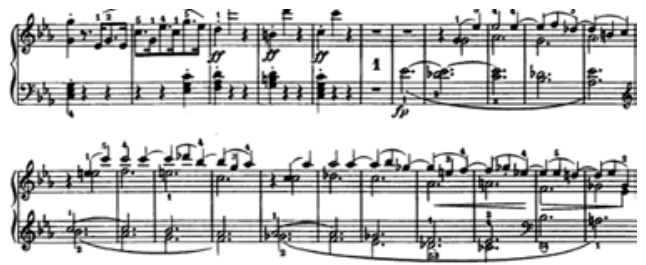

Главная партия, 1-я часть 21-й сонатыл Л. Бетховена

Побочная партия, 1-я часть 21-й сонатыл Л. Бетховена (тm. 4-10)
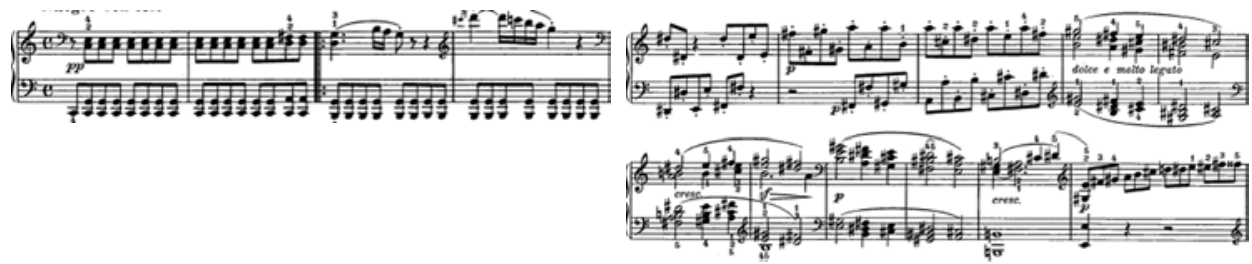

Прямоугольники, вытянутые вверх, воспринимаются как выражение не только стройности и элегантности, но и как выражение стремления к «высокому» ${ }^{12}$.

В эпоху романтизма уход от симметрии квадратного периода был выражением динамики становления чувства, динамики событийности. Поэтому вполне логично, что строение темы стало больше напоминать треугольники с разнообразными формами смещения вершины в правую или левую сторону. Так, треугольник со смещённой вершиной вправо мы находим и в первых частях 5-й, 8-й, 23-й сонат Л. Бетховена, в менуэте Симфонии № 40 В. Моцарта. Такое строение темы служит выражением «направленной остроактивной динамики» ${ }^{13}$, показывая агрессивность, «неуживчивость» одного из элементов темы. В то же время начало темы с вершины источника, смещая вершину треугольника влево, обусловливает более спокойное, умиротворённое состояние, объясняющееся спадом волны, как, например, в ноктюрне Шопена Des-dur. В музыке можно найти воплощение и равнобедренных, симметричных треугольников, как, например, в теме радости в 4-й части Девятой симфонии Л. Бетховена и номере «Джульетта-девочка» из балета С. Прокофьева «Ромео и Джульетта».

Так, рассмотрев действие двух важных принципов (простоты и влияния геометрии формы на эмоциональные свойства объекта), действующих в визуальном восприятии человека, мы понимаем, что сама онтология категории пространства обусловливает существование ряда универсальных законов, обеспечивающих

12. Там же. С. 19.

13. Там же. C. 20. 
сближение разных видов искусства в акте художественного творчества и восприятия. Закономерно, что из взаимодействия средств музыкальной выразительности постепенно в сознании слушателя формируется образ, обладающий определёнными пространственными и визуальными характеристиками, помогающими распознать его реальный прототип, его художественные смыслы и значения.

В итоге можно констатировать, что процесс музыкального восприятия напрямую зависим от протекания и результатов разных видов мышления, опирающихся на уже имеющиеся знания о реальности и специфике её отражения. Важными составляющими в восприятии являются характер организованности мыслительных процессов (внимания, воображения, памяти); темп осуществления мыслительных операций (анализа, синтеза, сравнения, обобщения, конкретизации и абстракции) и множество других внутренних индивидуальных свойств и качеств человека. Понимание этих закономерностей возможно не только исходя из исследования психофизиологии человека, но и, наоборот, через изучение принципов воздействия искусства на человека в междисциплинарном аспекте.

\section{БИБЛИОГРАФИЯ}

1. Арнхейм Р. Искусство и визуальное восприятие / Р. Арнхейм.- М.: Прогресс, 1974.C. 12 .

2. Бонфельд М.Ш. Музыка: Язык. Речь. Мышление. Опыт системного исследования музыкального искусства. - СПб.: Композитор, 2006. - 648 с.

3. Веккер Л. М. Психика и реальность: единая теория психических процессов / Л. М. Веккер; общ. ред. А. В. Либина.- М.: Смысл, 2005.— 587 с.

4. Казанцева Л.П. Содержание музыкального произведения в контексте художественной культуры / Л.П. Казанцева.- Астрахань: Волга, 2005.- 112 с.

5. Крючкова К. К. Композиция в дизайне / К. К. Крючкова. — Майкоп: Магарин О. Г., 2014.$426 \mathrm{c}$.

6. Райков В. Л. Значение понимания сознания / В. Л. Райков.- М.: Синергия, 2005.-164 с.

7. Рыжкин И. Я. Теория ладового ритма / И. Я. Рыжкин, Л. А. Мазель. Очерки по истории теоретического музыкознания.- М.; Л., 1939. Вып. 2.— 286 с.

8. Свешников А. В. Интегральное мышление и искусство / А. В. Свешников. - М.: Университетская книга, 2017.- 324 с.

9. Цукерман В.А. Анализ музыкальных произведений / В. А. Цукерман, Л. А. Мазель.М.: Музыка, 1975.- С. 677.

10. Этинген Л. Е. Мифологическая анатомия / Л.Е. Этинген.- М.: Институт общегуманитарных исследований, 2009.-344 с.

11. Kuo Hao Tang. Assessment of the subjective perception of music quality using psychoacoustic approach / Kuo Hao Tang // International Journal of Industrial Ergonomics. - 2016. - Vol. 53. - Pp. 219-228. 